REPORTS OF MORPHOLOGY
$\begin{gathered}\text { Official Journal of the Scientific Society of Anatomists, } \\ \text { Histologists, Embryologists and Topographic Anatomists } \\ \text { of Ukraine } \\ \text { journal homepage: https://morphology-journal.com }\end{gathered}$

\title{
Features of the thyroid gland structural components remodeling in the toxemia stage after experimental thermal injury
}

\section{Koritskiy V.G., Nebesna Z.M.}

SHEI "I. Horbachevsky Ternopil State Medical University Ministry of Health of Ukraine", Ternopil, Ukraine

\begin{tabular}{|c|c|}
\hline $\begin{array}{l}\text { UDC: } 616.441-003.93-02.616-001.17]- \\
092.9 \\
\text { CORRESPONDING AUTHOR } \\
\text { e-mail: nebesna_zm@tdmu.edu.ua } \\
\quad \text { Nebesna Z.M. }\end{array}$ & $\begin{array}{l}\text { Thermal injury causes severe structural and metabolic disturbances not only of the } \\
\text { skin itself, but also of all organs and systems of the affected organism, is a manifestation } \\
\text { of a complex symptom complex - a burn disease. Of particular importance in patients } \\
\text { with burns are changes in the endocrine system. The aim of the study was to establish } \\
\text { the microscopic and electron-microscopic reorganization of the components of the } \\
\text { thyroid gland of animals after thermal damage on } 14 \text { day after experimental thermal } \\
\text { injury. A III degree burn was applied under ketamine anesthesia with copper plates } \\
\text { heated in boiled waterto a temperature of } 97-100^{\circ} \mathrm{C} \text {. The size of the lesion area was } 18- \\
20 \% \text { of the epilated surface of the body of rats. An experimental study of the structural } \\
\text { components of the thyroid gland after a burn injury was performed on laboratory white } \\
\text { male rats weighing } 160-180 \text { g. Rats euthanasia was performed after ketamine anesthesia } \\
\text { by decapitation. In the experiment, the study of the microscopic and submicroscopic } \\
\text { state of the follicles and hemocapillaries of the thyroid gland after thermal injury of the } \\
\text { III degree. It has been established that in the toxemia stage after the application of the } \\
\text { burn injury on } 14 \text { day (late toxemia stage), significant destructive and degenerative } \\
\text { changes are found in the thyrocytes of the wall of the follicles and hemocapillaries, the } \\
\text { organ acquires a macrofollicular structure. The height of thyrocytes decreases, the } \\
\text { nuclei and organelles of cytoplasm are significantly damaged, the number and height } \\
\text { of microvilli on their apical surface decreases, which negatively affects the cell's } \\
\text { secretory cycle and transcapillary organ metabolic processes. The established } \\
\text { destructive changes in the blood capillaries and thyrocytes of the follicles are the } \\
\text { morphological manifestation of the suppression of the secretory activity of the thyroid } \\
\text { gland during thermal injury and corresponds to the hypofunctional state of the organ. } \\
\text { Keywords: thyroid gland, microscopic and submicroscopic changes, thermal skin } \\
\text { injury. }\end{array}$ \\
\hline
\end{tabular}

\section{Introduction}

The study of the pathogenesis of organs in the composition of the body systems after severe thermal trauma is an urgent problem of combustiology [12, 15, 21]. Today, the frequency of burns in developed countries is 1: 1000 per year, and the mortality, despite the use of modern treatments, remains fairly high and ranges from $5.9 \%$ to $21.2 \%$ [12, 13 , $15,17,21,24,25,26]$. In the case of severe thermal trauma, there are a number of factors that lead to sepsis and multiple organ failure: microcirculation disorder, presence of necrotic tissues inhabited by wounds, endogenous intoxication, activation of lipid peroxidation, development of syndrome of systemic inflammatory response, DIC, etc. $[2,3,5,6,7,10$, $13,14,20]$. It has been established that in the complicated and inadequately studied pathogenesis of burn disease one of the main places has endogenous intoxication, which is the result of proteolysis of damaged tissues and alteration of histo-hematological barriers. Hormonal changes are involved not only in triggering mechanisms of the pathogenesis of burn disease, but also in the development of compensatory-adaptive responses and the mobilization of protective functions of the organism [4, 11, 16, 19, 23]. Particularly important role in this complex process belongs to the systems of the pituitary gland - adrenal cortex, the pituitary gland - thyroid gland. They represent not only an intermediate link in the efferent pathways of the nerve regulation, but also are peripheral endocrine effector that provides a balance of metabolic and regenerative processes.

Today, we know about the ability of the thyroid gland to 
morphofunctional reorganization under the influence of endo- and exogenous factors [1, 18, 19]. However, the status of this organ in the process of adaptation processes remains poorly understood.

The aim of the work was to establish microscopic and electron microscopic reorganization of the components of the thyroid gland of animals after thermal lesions in the stage of toxemia after an experimental thermal trauma.

\section{Materials and methods}

Experiments were conducted on 20 sexually mature white male rats. The animals were kept on a standard diet by the vivarium of the State Higher Educational Institution "I. Horbachevsky Ternopil State Medical University Ministry of Health of Ukraine". Animal care and all manipulations were conducted in accordance with the provisions of the "European Convention for the Protection of Vertebrate Animals Used for Experiments and for Other Scientific Purposes" (Strasbourg, 1986), as well as in accordance with the provisions of the "General Ethical Principles of Experiments on animals", adopted by the First National Congress on Bioethics (Kyiv, 2001).

Burns of the third degree were applied under ketamine anesthesia with copper plates heated in boiled water to a temperature of $97-100^{\circ} \mathrm{C}[7,22]$. The size of the lesions was $18-20 \%$ of the shaved surface of the body of rats. At daily inspection, we monitored their overall condition, the degree of manifestation of local changes in the area of burn wound, body weight and mortality. The object of the study was thyroid gland. To study micro and submicroscopic changes, animals were decapitated under ketamine anesthesia at 14 day, which, according to presentations, corresponds to the stage of late toxemia of burn disease [21].

Material for microscopic research was taken according to the generally accepted method [8]. Sections of the thyroid gland were fixed in a $10 \%$ neutral formalin solution, dehydrated in alcohols of increasing concentration, poured in paraffin blocks. The cut-offs of 5-6 microns thickness were stained with hematoxylin-eosin and methylene blue [8]. The histological preparations were studied using MIKROmed SEO SCAN light microscope and photo-documented with a Vision CCD Camera with a histologic image display system. For electron microscopic studies, we took pieces of the thyroid gland, fixed them in a $2.5 \%$ solution of glutaraldehyde, fixed with a $1 \%$ solution of osmium tetroxide on phosphate buffer. Further processing was carried out in accordance with the generally accepted method [8]. Ultra-thin sections made on ultramicrotome UMPT-7 were contrasted with uranyl acetate, lead citrate according to the Reynolds method and studied in an electron microscope of PEM-125K.

\section{Results}

According to conducted histological studies of experimental animals, after an experimental thermal trauma in the organ, there are heterogeneous in shape and size follicle. Prevailing large over-stretched with a dense, oxyphilic

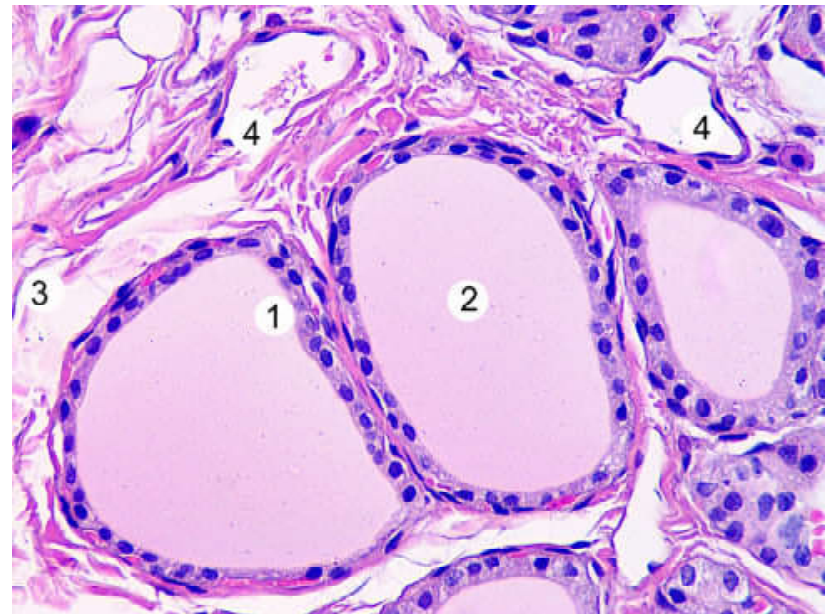

Fig. 1. Microscopic changes of the thyroid gland 14 days after the experimental thermal trauma. Large, over-stretched follicles (1), colloid (2), perifollicular edema of the connective tissue (3) of the vessel (4). Hematoxylin-eosin. x 200.

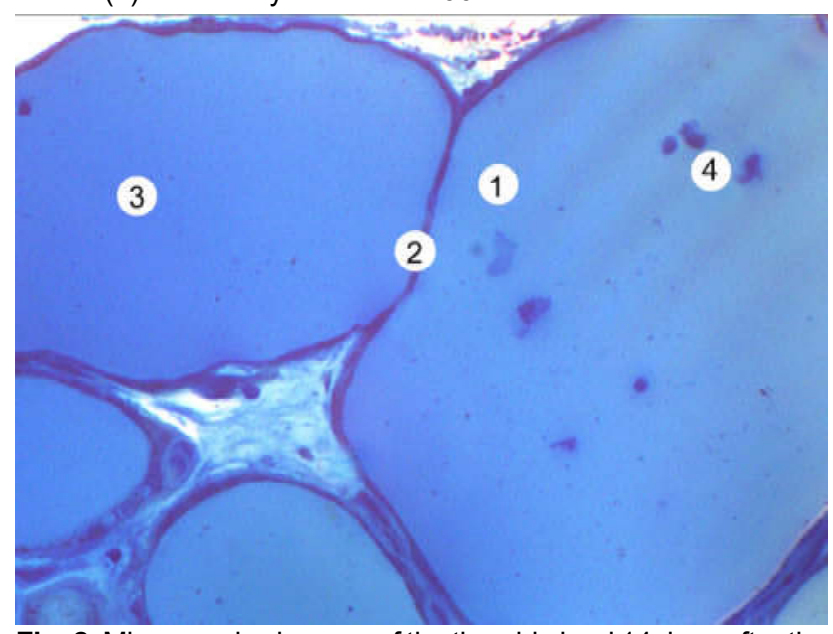

Fig. 2. Microscopic changes of the thyroid gland 14 days after the experimental thermal trauma. Large, over-stretched follicles (1) with flat thyrocytes in the wall (2), colloid (3), desquamated thyrocytes in the lumen of the follicle (4). Methylene blue. x200.

colloid, in which vacuole resorption is absent. Thyrocytes of such follicles have a flattened form and hyperchromic, picnotically altered nuclei. Desquamation of the thyroid gland epithelium is also revealed in the lumen of the follicle (Fig. 1, Fig. 2).

In the central parts of the lobules, also observed single deformed, medium and small follicles, in which the thyrocytes have cubic or prismatic form, light cytoplasm, normochromic, centrally located nuclei. The colloid in such follicles was not much, it was loose and acquired a disperse form, numerous and large vacuoles of resorption, which sometimes merged into illuminated strips, were found. Interfollicular, interstitial of connective tissue is moderately swollen.

During this period of the experiment, changes in the organ vascular and microcirculatory system, manifested by plethora, stasis, are detected. The expansion capillaries are 


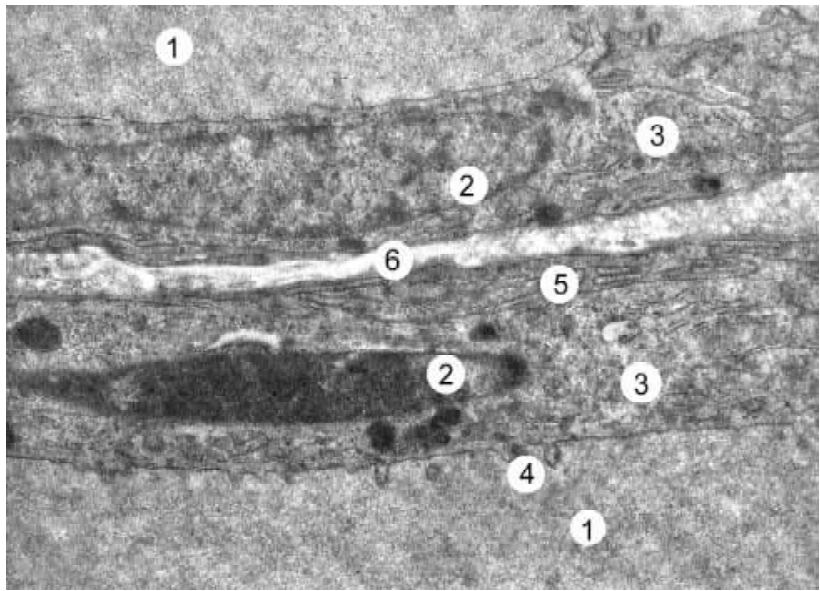

Fig. 3. Submicroscopic organization of the wall of the follicles of the thyroid gland 14 days after the experimental thermal trauma. Enlargement of the follicle with dense colloid (1), flat nucleus (2) and cytoplasm of thyrocyte (3), single microvilli on the apical surface of the cell (4), branching of the basal surface of the thyrocyte (5), basement membrane (6). x9000.

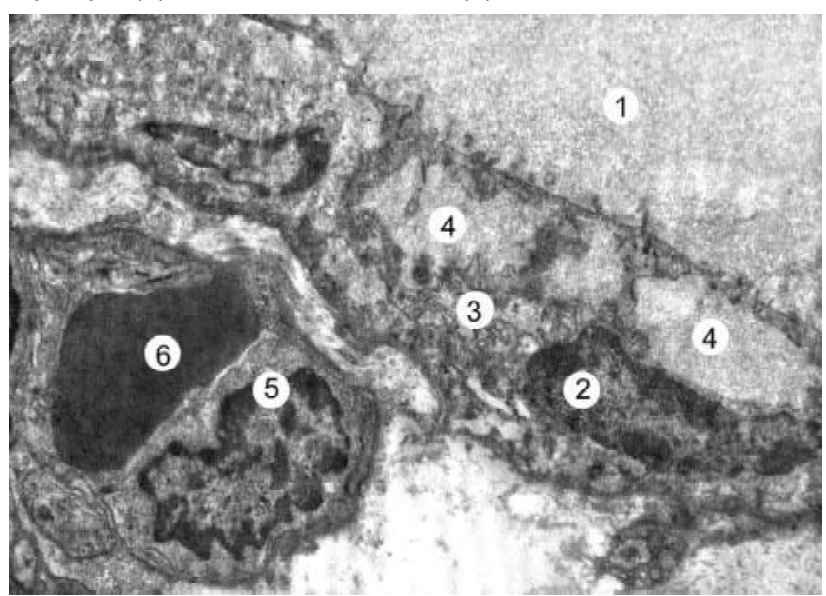

Fig. 4. Submicroscopic organization of the thyroid gland 14 days after the experimental thermal trauma. Enlargement of the follicle with colloid (1), osmophilic, fused nucleus (2) and cytoplasm (3) of the thyrocyte, large vacuolic structures (4), endothelial cell (5), erythrocyte in the lumen of the capillary (6). x7000.

densely surrounded by follicles and has expanded and narrowed areas of their lumens. In their wall there are hypertrophied, edematous endothelial cells, as well as densified, picnotic. Around the hemocapillaries there is significant perivascular space.

Submicroscopically in enlarged follicles, thyrocytes have a flattened form, poorly contoured borders between the cells. There are no microvilli on their luminal surface. In the swollen, enlightened cytoplasm, organelles are numb and significantly destructively altered. In the flat form of nuclei there is an electron-transparent karyoplasm, which includes small ectopic nucleoli. The outer membrane of nuclear membrane sometimes expands, increasing perinuclear space. Observed areas of a condensed osmophilic karyoplasm, which reduces the clarity of the nuclear membrane. Also decreases the number of nuclear pores. On the surface of the fragmented and thickened tubules, the granular endoplasmic net has little ribosomes, as well as free ribosomes and polysomes in the cell cytoplasm. Expansion and deformation of the granulosa endoplasmic mesh channels lead to the formation of large cavities of irregular shape, limited by unclearly contoured membranes (Fig. 3).

Circular vesicles of the Golgi complex sometimes expanding or vice versa considerably narrowing, their length extends. Available, primary and secondary lysosomes, which are freely located in the cytoplasm and near the Golgi complex. Damage to the mitochondria is accompanied by significant illumination of the matrix. A small number of cristae is contained in swollen electron-transparent mitochondria. Also, an irregular shape of the mitochondria with uneven contours of the outer membranes, which may be partially destroyed, is observed. Separate mitochondria have the appearance of large vacuoles. In the cytoplasm of the cells, an insignificant amount of apical grains is detected and large, irregularly shaped, vacuolic structures are filled with colloid (Fig. 4).

The need to intensify the metabolic processes of the affected organism causes the activation of the work of the synthetic apparatus of the thyrocytes: the tubules and circular vesicles of the granular endoplasmic net, which are concentrated at the basal pole, numerical polysomes, and the mitochondria have clearly contoured cristae, are expanding. The membranes of the basal part of the thyrocytes form a kind of labyrinth of branches, which are compensatory adapted changes to ensure the withdrawal of the hormone (Fig. 4).

It has been established that at separate sites in the follicles, the thyrocytes do not adhere tightly to the wall of the

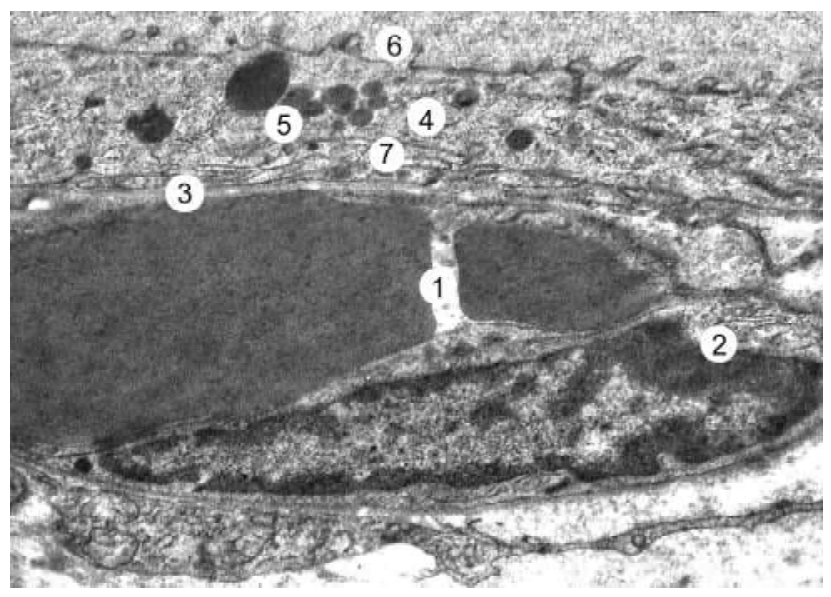

Fig. 5. Submicroscopic organization of the wall of the thyroid gland 14 days after the experimental thermal trauma. Enlargement of the capillary with erythrocytes (1), endothelial cell (2), capillary basement membrane (3), flat form of thyrocyte cytoplasm (4), primary and secondary lysosomes (5), microvilli on the apical surface of the cells (6), branching of the basal surface of the thyrocytes (7). x12000. 
hemocapillaries, and separate from them by layers of connective tissue. Connective tissue strip looks edematous, has an electronically bright amorphous component and separate collagen fibrils.

The ultrastructure of blood capillaries is changing. Most of them have extensive erosions filled with erythrocytes. Endothelial cells are significantly altered, their nuclei are picnotically altered, they have elongated shape and deep invaginations of nuclear membrane. The perinuclear space between the membranes of the nuclear membrane is poorly expressed. The content of condensed heterochromatin increases, it forms large osmophilic clusters. In the cytoplasm there are few organelles and foamy cystic bubbles, their plasmalemma of the luminal surface is uneven and microvilli are single. In the cytoplasmic subtle areas, there is little fenestra. Such hemocapillaries are limited by narrow basal membranes (Fig. 4, Fig. 5).

\section{Discussion}

Histological studies have shown that changes in the structural components of the thyroid gland follicles during the experimental thermal trauma develop in the background of microcirculation disturbance, which is to some extent consistent with the studies [1, 7, 11, 21]. Significantly disturbed ultrastructure of the walls of perifollicular blood capillaries. Dystonia of blood vessels, which is detected on a burn injury on light optic and especially on submicroscopic levels, is manifested by enlargement, plethora, stasis and significant destructive changes in the walls of blood capillaries.

Activation of free-oxidation of lipids leads to the destruction of phospholipids of cell membranes. Such a statement about the mechanism of cellular membrane damage is consistent with the results of our research and [20,21], which established a high level of toxic substances of lipid peroxidation in blood plasma of animals under investigation during thermal trauma. In this connection, it can be assumed that being in the blood, peroxides and free radicals primarily cause damage to the membranes of endothelial cells of the capillaries, and in the future, when they reach the bloodstream in the tissues, they lead to the destruction of the plasmalemma and organelles of the membranes of all organs of the affected organism, including thyroid gland.

It is known that the mechanisms of adaptation to hypoxia are realized on the principle of stress reactions with the participation of the hypothalamic-pituitary-adrenal system, the least explored is the role of the hypothalamic-pituitarythyroid system [2, 3, 4, 10, 11, 23]. In the scientific literature, there is virtually no data on the participation of hormones in

\section{References}

[1] Boychuk, T. M., Khodorovskaya, A. A., Chala, K. M., Chernikova, G. M., \& Khodorovsky, V. M. (2011). Morphometric indices of functional activity of the thyroid gland under stress reaction. Bukovinsky medical bulletin, 15(2), (58), 89-91.

[2] Cherkasov, V. G., Kovalchuk, A. I., Dzevulskaya, I. V., Malikov, A.V., Lakhtadyr, T.V., \& Matkivskaya, R. M. (2015). Structural transformations in the internal organs with infusion therapy adapting to high temperatures. In the early stages of adaptation to hypoxia, hyperfunction of the thyroid gland and increased levels of thyroid hormones in the blood, which correlate with increased metabolism, is observed [1]. With prolonged action, hypofunction of the gland was noted under the conditions of "minimization" of metabolic functions and reduction of metabolism [1].

It is necessary to note the important role of thyroid hormones in the adaptation processes, since they have almost the widest spectrum of influence, since under their control are lipid, carbohydrate, protein and water-salt metabolism, as well as regeneration processes, permeability of cell membranes, etc.

In the scientific literature, the flow of compensatory and adaptive processes in the thyroid gland and its reorganization under conditions of stress, under the conditions of burn injury, have not been sufficiently studied. At morphological study of thyroid gland it is established that in the conditions of stress the volume of stromal elements of the organ increases, volume density of thyrocytes decreases, volume of colloid increases, the thyroid epithelium flings up. In some cases desquamation of thyrocytes occurs. If the stimulus is very strong or recurrent, then the resistance stage goes into the stage of exhaustion, there is a decrease in the function of the thyroid gland.

Thus, the results of histological studies correlate with the scientific data of other researchers $[5,14,21]$ and indicate that in the stage of late toxemia after severe thermal trauma the destruction of membrane structural components of thyroid gland cells is significantly increased, which is necessarily accompanied by the development of dystrophic and necrobiotic processes in the body, a decrease in the secretory process.

In subsequent studies, it is planned to establish the degree of morphological changes in the structural components of the thyroid gland in the dynamics after the experimental thermal trauma under the use of corrective drugs.

\section{Conclusions}

In the stage of late toxemia after the thermal trauma in rats, deep irreversible destructive changes in thyrocytes in the follicles and hemocapillars of the thyroid gland develop, which are manifested by deep lesions of plasma, nuclear and intracellular membranes, leading to a decrease in secretion and excretion of hormones, a violation of transendothelial metabolism, and corresponds to the hypofunctional state of the organ.

for burn disease. Medical science of Ukraine, 11(3-4), 4-11. [3] Dzevulska, I. V., Kovalchuk, O. I., Cherkasov, E. V., Majewskyi, O. Ye., Shevchuk, Yu. G., Pastukhova, V. A. \& Kyselova, T. M. (2018). Influence of lactoproteinum solution with sorbitol on dna content of cells of endocrine glands on the background of skin burn in rats. World of Medicine and Biology, 64(2), 033-039. doi: 10.26724/2079-8334-2018-2-64-33-39 
[4] Dzevulska, I. V. (2015). Monthly rates of cell cycle of rat adrenal cells in administration of $0,9 \% \mathrm{NaCl}$ solution, Lactoprotein with sorbitol or HAES-LX-5\% during the first 7 day. Biomedical and Biosocial Anthropology, 25, 33-37.

[5] Evers, L. H. (2010). The biology of burn injury. Exp. Dermatol, 19(2), 9, 777-783 doi:10.1111/j.1600-0625.2010.01105.x

[6] Farina, Jr., J. A., Rosique, M. J., \& Rosique, R. G. (2013). Curbing inflammation in burn patients. International Journal of Inflammation, 2013, 1-9. doi: 10.1155/2013/715645

[7] Galunko, G. M. (2017). Histological changes in the small intestine in the advanced stages of burn disease. World of Medicine and Biology, 3(61), 90-96. doi: 10.26724 / 2079-8334-2017-361-90-96

[8] Gunas, I., Dovgan, I., \& Masur, O. (1997). Method of thermal burn trauma correction by means of cryoinfluence. Abstracts are presented in zusammen mit der Polish Anatomical Society with the participation of the Association des Anatomistes Verhandlungen der Anatomischen Gesellschaft, Olsztyn ( $p$. 105). Jena - Munchen: Der Urban \& Fischer Verlag.

[9] Goralskiy, L. P., Homich, V. T., \& Kononskiy, O. I. (2011). Fundamentals of histological technique and morphofunctional methods of research in norm and in pathology. Zhitomir: Polissya.

[10] Gunas, I. V., Guminskiy, Yu. I., Ocheretna, N. P., Lysenko, D. A., Kovalchuk, O. I., Dzevulska, I. V., \& Cherkasov, E. V. (2018). Indicators cell cycle and dna fragmentation of spleen cells in early terms after thermal burns of skin at the background of introduction $0.9 \% \mathrm{NaCl}$ solution. World of Medicine and Biology, 1(63), 116-120. doi: 10.26.724/2079-8334-2018-1-63-116-120

[11] Gunas, I. V., Kovalchuk, O. I., Cherkasov, V. G., \& Dzevulskaya, I. V. (2014). Structural aspects of the organs adaptive changes of the neuroimundocrine system in the treatment of burn disease with combined hyperosmolar solutions. Galician Medical Herald, 21(2), 21-26.

[12] Janak, J. C., Clemens, M. S., Howard, J. T., Le T. D., Cancio, L. C., Chung, K. K., \& Stewart, lan J. (2018). Using the injury severity score to adjust for comorbid trauma may be double counting burns: implications for burn research. Burns, 44, 8, 1920-1929. doi: 10.1016/j.burns.2018.03.012

[13] Jeschke, M. G., Pinto, R., \& Kraft, R. (2015). Inflammation and the Host Response to Injury Collaborative Research Program. Morbidity and survival probability in burn patients in modern burn care. Crit. Care. Med, 43(2), 4, 808-815.

[14] Kallinen, O., Maisniemi, K., Bohling, T., Tukiainen, E., \& Koljonen, V. (2012). Multiple organ failure as a cause of death in patients with severe burns. J. Burn Care Res., 33(2), 206-211. doi: 10.1097/BCR.0b013e3182331e73

[15] Kearney, L., Francis, E. C., \& Clover, A. J. (2018). New technologies in global burn care - a review of recent advances. Int. J. Burns Trauma, 8(4), 77-87. PMID: 30245912

[16] Kovalchuk, O. I. (2016). Features of cell cycle indices in the adenohypophysis at late terms post-burn skin injury in rats under separate infusion in the first 7 days of $0.9 \%$ solution of $\mathrm{NaCl}$, lactobacillus solutions with sorbitol or HAES-LX-5\%. Ukrainian Scientific Medical Youth Journal, 93(1), 24-31.

[17] Maden, M. (2018). Optimal skin regeneration after full thickness thermal burn injury in the spiny mouse. Acomys cahirinus. Burns, 44, 6, 1509-1520. doi: 10.1016/j.burns.2018.05.018

[18] Nurmetova, I. K., \& Kuhar, I. D. (2012). Organometric parameters of thyroid gland in rats with acute burned toxemia on the background of treatment with infusion drugs. Ukrainian Journal of Hematology and Transfusiology, 15(4), 278-281.

[19] Nurmetova, I. K. (2012). Morphometric parameters of the thyroid gland during thermal trauma in the dynamics of its experimental treatment with combined hyperosmolar solutions on the 21st and 30th day of the experiment. Reports of Morphology, 18(2), 263-265.

[20] Nebesna, Z. M., Lisnichuk, N. Ye., \& Demkiv, I. Ya. (2015). Dynamics of changes of oxidation-reduction reactions in the lung tissue in case of burn injury and its correction by lyophilized xenograft substrate. Bulletin of Biology and Medicine, 4(1), (124), 124-128.

[21] Netyukhailo, L. G., Kharchenko, A. G., \& Kostenko, S. V. (2011). Pathogenesis of burn disease (in 2 parts). World of Medicine and Biology, 1, 127-131, 131-135.

[22] Regas, F. C., \& Ehrlich, H. P. (1992). Elucidating the vascular response to burns with a new rat model. J. Trauma, 32, 5, 557-563.

[23] Strelchenko, Yu. I., Zyablytsev, S. V., \& Yale, V. M. (2012). Pathophysiological relationships of pituitary-thyroid and pituitary-adrenal systems under the influence of polarized light in rats with dosed burns to open flames. Clinical and Experimental Pathology, 11(2), 3, 156-158.

[24] Swanson, J. W., Otto, A. M., Gibran, N. S., Klein, M. B., Kramer, C. B., Heimbach, D. M., \& Pham, T. N. (2013). Trajectories to death in patients with burn injury. J. Trauma Acute Care Surg., 74(1), 282-288. doi: 10.1097/TA.0b013e3182788a1c

[25] Takayuki, Y., Hayato, I., Timothy, W., King, H., Hara, D., \& Cooper, K. (2018). Skin xenotransplantation: Historical review and clinical potential. Burns, 44(8), 1738-1749, doi: 10.1016/ j.burns.2018.02.029

[26] Timmers, T. K., Verhofstad, M. H., \& Leenen, L. P. (2015). Intensive care organisation: Should there be a separate intensive care unit for critically injured patients? World Journal of Critical Care Medicine, 4, 240-243. doi:10.5492/ wjccm.v4.i3.240

\section{ОСОБЛИВОСТІ РЕМОДЕЛЮВАННЯ СТРУКТУРНИХ КОМПОНЕНТІВ ЩИТОПОДІБНОЇ ЗАЛОЗИ В СТАДІЇ ТОКСЕМІЇ ПІСЛЯ ЕКСПЕРИМЕНТАЛЬНОї ТЕРМІЧНОї ТРАВМИ \\ Корицький В.Г., Небесна 3.М.}

Термічна травма спричиняє тяжкі структурно-метаболічні порушення не тільки безпосередньо шкірного покриву, але й усіх органів та систем ураженого організму, що є проявом складного симптомокомплексу - опікової хвороби. Особливе значення у хворих з опіками відіграють зміни органів ендокринної системи. Метою дослідження було встановлення мікроскопічної та електронно-мікроскопічної реорганізації компонентів щитоподібної залози тварин після термічного ураження на 14 добу після експериментальної термічної травми. Опік III ступеня наносили під кетаміновим наркозом мідними пластинами, нагрітими у киплячій воді до температури 97-100 епільованої поверхні тіла щурів. Експериментальне вивчення структурних компонентів щитоподібної залози після опікової травми було виконано на лабораторних білих щурах-самцях масою 160-180 г. Евтаназію щурів проводили після кетамінового наркозу шляхом декапітації. В експерименті вивчили мікроскопічний та субмікроскопічний стан фолікулів та гемокапілярів щитоподібної залози після термічної травми III ступеня. Встановлено, що в стадії токсемії після нанесення опікової травми - 14 доба (стадія пізньої токсемії) в тироцитах стінки фолікулів та гемокапілярах виявляються значні деструктивні 
та дегенеративні зміни, орган набуває макрофолікулярної будови. Знижується висота тироцитів, значно пошкоджуються ядра і органели цитоплазми, зменшується кількість і висота мікроворсинок на їх апікальній поверхні, що негативно впливає на секреторний цикл клітин та транскапілярні обмінні процеси органу. Таким чином, встановлені деструктивні зміни кровоносних капілярів та тироцитів фолікулів є морфологічним проявом пригнічення секреторної активності щитоподібної залози при термічній травмі та відповідає гіпофункціональному стану органу.

Ключові слова: щитоподібна залоза, мікроскопічні та субмікроскопічні зміни, термічна травма шкіри.

\section{ОСОБЕННОСТИ РЕМОДЕЛИРОВАНИЯ СТРУКТУРНЫХ КОМПОНЕНТОВ ЩИТОВИДНОЙ ЖЕЛЕЗЫ В СТАДИИ ТОКСЕМИИ ПОСЛЕ ЭКСПЕРИМЕНТАЛЬНОЙ ТЕРМИЧЕСКОЙ ТРАВМЫ \\ Корицкий В.Г., Небесная З.М.}

Термическая травма вызывает тяжелые структурно-метаболические нарушения не только непосредственно кожного покрова, но и всех органов и систем пораженного организма, является проявлением сложного симптомокомплекса ожоговой болезни. Особое значение у больных с ожогами играют изменения органов эндокринной системы. Целью исследования было установление микроскопической и электронно-микроскопической реорганизации компонентов щитовидной железы животных после термического поражения на 14 сутки после экспериментальной термической травмы. Ожог III степени наносили под кетаминовым наркозом медными пластинами, нагретыми в кипящей воде до температуры 97-100 C. Размеры участка поражения составляли 18-20\% эпилированной поверхности тела крыс. Экспериментальное изучение структурных компонентов щитовидной железы после ожоговой травмы были выполнены на лабораторных белых крысах-самцах массой 160-180 г. Эвтаназию крыс проводили после кетаминового наркоза путем декапитации. В эксперименте изучили микроскопическое и субмикроскопическое состояния фолликулов и гемокапилляров щитовидной железы после термической травмы III степени. Установлено, что в стадии токсемии после нанесения ожоговой травмы на 14 сутки (стадия поздней токсемии) в тироцитах стенки фолликулов и гемокапиллярах обнаруживаются значительные деструктивные и дегенеративные изменения, орган приобретает макрофолликулярное строене. Снижается высота тироцитов, значительно повреждаются ядра и органеллы цитоплазмы, уменьшается количество и высота микроворсинок на их апикальной поверхности, что отрицательно влияет на секреторный цикл клеток и транскапиллярные обменные процессы органа. Таким образом, установленные деструктивные изменения кровеносных капилляров и тироцитов фолликулов являются морфологическим проявлением подавления секреторной активности щитовидной железы при термической травме и соответствует гипофункциональному состоянию органа.

ключевые слова: щитовидная железа, микроскопические и субмикроскопические изменения, термическая травма кожи. 